\title{
Intellectual Type of Creativity (Poetry)
}

\author{
Irina I. Plekhanova* \\ Irkutsk State University \\ 2 Chkalova Str., Irkutsk, 664025, Russia
}

Received 02.03.2015, received in revised form 09.04.2015, accepted 10.06.2015

On the example of poetry, this paper explores intellectual modus of creativity as expression of tendency of artistic thinking in the 20th century. Intellectualization is interpreted as "directed thinking" (C. G. Jung), i.e. rationality that dominates in creativity. The paper outlines defining mindsets of intellectual type of creativity: self-consciousness of art, reflection of gnosis, priority of aesthetics over ethics, alienated lyricism. Diversity of forms is illustrated by poetic examples of older symbolist V. Bryusov, futurist V. Khlebnikov, member of the absurdist group OBERIu N. Zabolotsky, neofuturist $N$. Glazkov, naturalistic philosopher A. Tarkovsky and minimalistic conceptualist $V$. Nekrasov. Intellectual type of creativity, along with visibly frozen spiritual processes, shows specific passion for possessing the absolute truth. This truth can be shown as universal idea (for instance, common unity, panlogism, hylozoism) or as a way of thinking (in examined cases - as aestheticism, Glazkov's unprecedentism, conceptualism), which maximally approached the undogmatic, heuristic understanding of essence of nature of things and relations.

Keywords: intellectualization, "directed thinking", lyrics of 20th century, self-consciousness of art, reflection of gnosis, priority of aesthetics, alienated lyricism.

DOI: 10.17516/1997-1370-2015-8-7-1351-1359

Research area: philology.

The need for distinguishing the intellectual type of creativity is associated with an obvious shift in the social and cultural mindsets of human in technological, information, urban society, when civilizational processes stimulate and reinforce the dominance of the left hemisphere in any type of mental activity (Ershova, 2003). Discussions about the degree of specialization in cognitive ways, on the structure of consciousness itself (Dubrovskii, 2009), as well as about the prospects of "fusion of people with computers" (Chernigovskaia, 2013, p. 18), discuss actively the specifics of cognitive processes, the relationship of language and thought, but not their artistic expression and consequences. Intellectual activity, a component of human, both biological and social nature in general, develops along the self-sufficient vector that is realized in a shift towards rationalization, reasoning, speculative preconception of spiritual, professional, creative activities. These factors create an apparent lack of terms to describe the nature of the trend.

The common formula of "mass and elite" (Dubin, 2010) suggests the antithesis of manipulated low and independent high art with the already known polar assessment of

(C) Siberian Federal University. All rights reserved

* Corresponding author E-mail address: oembox@yandex.ru 
their content and creativity. But it is obvious that the commercial success of the first, and mostly provocative intention of the second (in the aesthetics of contemporary art) are equally conditioned by the professionally presupposed effect, i.e. alienated generation of the text as a communication strategy. Variation of modes, proposedbymodernliterarytheory(Tamarchenko, 2007), develops N. Fry's quartet and believes forms of conflict human self-consciousness in being a system-forming factor. These forms of conflict are either genetically set genres (tragedy, comedy, drama) or value-cognitive models of self-identity (heroism, eclogue, satire, irony). So anthropological and value shift in consciousness remains unaccounted; this shift changes the content of these basic concepts from rethinking to complete annihilation. Thus the irony of postmodernism deconstructed everything except itself. But the irony is a derivative of rational type of thinking, which prevailed in the $20^{\text {th }}$ century, i.e. this mode of artistic deterministic type of consciousness, which, after C.G. Jung, can be defined as "directed thinking", namely intellect (Jung, 2006, p. 598), which, opposed to thinking, depends on feeling. The characteristics of "directed thinking" in its artistic expression need to be described, which can be done on the example of poetry best.

The first step is to divide the quality and evaluation components of the concept of "intellectual". The intellectual type of creativity is a self-reflection of art, the natural consequence of the decomposition of immediacy myth-making, recognition of the intrinsic value of ideas and isolation of the individual creator. Historically, these processes started in ancient times, since the intellectual reflection is immanent for lyrics as the type of creative self-identity in the aesthetically specified form (Lirika, 2007). Though the intellectual origin has claimed to dominance in culture and art since the Enlightenment, but in reality it was approved as a priority in the era of modernism, strangely enough, precisely because of the constant presence it has no clear definition, recorded in any dictionaries, reference books or encyclopedias. Only some most common cognitive mindsets are obvious: the primacy of rational perception of the world, rather than sensual; the analysis prevails over the confidence in original reality, reflection dominates spontaneity; laughter concedes to irony. In creativity it is a rejection of the tradition of harmonic mimesis, the dictates of the theory, the implementation of the conceptual discovery, actualization of literary device, uncovered conventions, challenge for standards, the excellence of "made up thing" over the "unsophisticated". Social correlate is creative individualism: the author is immersed in self-awareness and is searching for a new, unprecedented language of art. This results in a variety of mindsets: from life-making experiments to gravitational deformation, estrangement, communicative difficulties, hermeticism, undemocratic behaviour, dehumanization, rejection of anthropocentrism. Range of thinking embraces both rationality and irrationality, but in any version for the author it is important "to resolve the idea", that is realize the idea, no matter how crazy it might be. The spectrum of artistic ideas in the $20^{\text {th }}$ century was brought up by positivism and had an inclination to the supersanity or overmind, as symbolism, futurism, cubism, abstractionism, suprematism, absurdism, stream of consciousness, and so on. Even attempts to return to the ingenuousness, to appeal to the primitive minimalism, archetypal constructs of popular culture are intelligent search of forms, an experiment, exposing the game nature of creative work.

The ultimate expression of intellectual activity gravitates to the modus "art for art" with a feeling of having been chosen among creators and recipients, which leads to a kind of 
evaluative apartheid, when "the art of caste, not democratic art" is recognized as genuine (Ortega y Gasset, 1991, p. 508), and the first differs from the second in a tendency "to the progressive elimination of the human, all too human elements (Ortega y Gasset, 1991, p. 507). Criticism of intellectualism - as the alienation of "pure" art from life; the author's overall solipsism, the focus on the device indicates the disastrous consequences especially for the Creator, who freed Himself from both the responsibility to the world, and the creation of the self, "this is in the split up $<\ldots>$ between art in general, i.e. all possible art form and the humanistic content, the human soul of the artist" (Veidle, 1996, p. 25). Criticism, of course, does not affect the process, and the trend of more and more radical alienation of artistic consciousness from the natural existence reaches its maximum in contemporary art, the Russian post-modern conceptualism. They claim to be the absolute intellectual freedom: spiritual, as they are certain about lack of illusion of their own position, aesthetic, as they work despite the classical categories, creative, because they show inexhaustible variety of methods of deconstruction of any meaning.

But, as shown by the discoveries of the avant-garde (V. Khlebnikov, N. Glazkov, D. Aygi, etc.), a priority of speculation itself, invention, nonsense or play with language and form do not directly lead to fragmentation of life and creative uses of poetry, as well as to its dehumanization, to the rejection of mystical revelation and faith. Similarly, the originality of intense thought does not necessarily require acute novelty of language that was emphasized by scathing V. Khodasevich: "I am longing for and talking. / Abstruse, perhaps, singing / Only an angel in front of God, / And cattle, not having seen God / bellow and roar carabbedly"1. At the same time the mastership of form, as the requirement of free will and clarity of mind, remained vitally important for the poet: "Oh, if my dying moan / was clothed in a clearly ode!" ("God is Alive! Clever, not Crabbed...” 1923) (Khodasevich, 1991, pp. 6365). Obviously, an indicator of belonging to a type of intellectual creativity is primarily a special type of consciousness, projective and reflective, which puts forward the idea and analyzes its own readiness to meet these categories. Common features of the type are manifested in poetic individualities corresponding to aesthetics of time and areas that they represent. Let us follow their examples from symbolic, lyrical poetry of V. Bryusov, futurist V. Khlebnikov, member of OBERIu N. Zabolotsky, neofuturist N. Glazkov, natural philosopher A. Tarkovsky, minimalistconceptualist V. Nekrasov. This set of names is a dotted variation of intelligent search in the poetry of the $20^{\text {th }}$ century.

Initial mindset of consciousness is the authenticity of artistic gnosis, i.e. undoubted relevance of accurate knowledge of poetic thought, when the mature idea is raised to become an anthropological statement. So V. Bryusov claimed the scientific objectivity of the hypothesis of the structural similarity of macro- and microcosm: "It may be that these electrons - / Worlds, where five continents / Art, knowledge, wars, thrones / And the memory of forty centuries! <..> Their wise men, their boundless world / Having put in the center of existence, / Hurry to get into the sparks of mystery / And philosophize as I do" ("The World of the Electron" of August 13, 1922) (Bryusov, 1972, p. 328). V. Khlebnikov formulated the idea of unity and proved the correctness of its accuracy in a poetic phrase: "I do not know, if the Earth is spinning or not, / It depends on whether a word fits the line. / I do not know whether my grandmother and grandfather were monkeys/ Monkeys, as I do not know if I want sweet or sour. / But I know that I want to boil, and I want to keep the sun / And my arm vein joined in common trembling" (1909) 
(Khlebnikov, 1986, p. 61). At the same time claims of poetic reason are rigorously tested for adequacy and some higher objective knowledge, as formulated by N. Zabolotsky: "And if a man could see / The horse's magic face, / He would tear out his feeble tongue / And give it to the horse. ("The Horse's Face", 1926) (Zabolotsky, 1985, p. 59). N. Glazkov asserted his vocation of the prophet and creator of the unprecedented words, being not confused by the sacred analogy: "I am Nicholas the Wonderworker, / Emperor of pages / I want not to echo someone, / But to establish the truth" ("Poetograd", 1940-1941) (Glazkov, 1989, p. 348).

A. Tarkovsky either postulated his belonging to the sacred tree of the language ("Dictionary", 1963), or suffered from impotence before the ineffable: "I am sick of words, words, words, / I cannot extol the right / To the reasonable speech, when all night on the roof / foliage is beating in rags, as a widow. / It turns out that I just cannot hear..."2 (1963-1968) (Tarkovsky, 1993, p. 253). V. Nekrasov, in accordance with his own theory of organic form, "speech as it is" and "speech as it wants" (Nekrasov, 2012, p. 192), objectified language reflection on the theme of the first verse of the Gospel of John: "The Word was God, // the Word is God / And thank God, // Thank God / If there is God" (Nekrasov, 2012, p. 177). So this rearrangement within a phrase with a change of verb forms, sounds and places of components changes the semantics of words and the essence of the spiritual formulas from faith to doubt.

Priority of a poetic way to the truth brings about the primacy of aesthetics over ethics. This is not necessarily an immorality's declaration, like Bryusov's verse: "Edge of knowledge and compassion / Heart will cross voluntarily, / In eternal abyss, without fatigue, / It will go forward, forward" ("I Would Have Died with Secret Joy...", 1898-1899 ) (Bryusov, 1972, p. 31). Cognitive mindset dismisses of the mission to preach "good and right feelings", precisely because intellectual consciousness is aimed at the discovery of the unknown, not recognizable, to expand the boundaries of understanding the complexity of the world. So new music of Khlebnikov's speech resonated with existential measure of the world: "I piped into my flute, / And the world wanted its wants. / Obedient to me recoiling stars were in the smooth circle. / I was piping my flute, carrying the world's fate" (Beginning, 1908) (Khlebnikov, 1986, p. 41).

In addition, N. Zabolotsky completed his "Columns"withapainfulpicture of transformation of aesthetics, which opened to the irrational, "the fighting elephants of subconscious": "Poetry in great agony / Breaks frenzied hands / Curses the whole world, / Wants to kill itself, / Once laughs crazy, / Twice rushes to the field, then suddenly / It lies in dust, with many pangs. <...> Poetry begins to look closely, / To study the movement of new figures / It begins to understand the beauty of clumsiness / the beauty of the elephant ejected from the underworld" ("Battle of Elephants", 1933) (Zabolotsky, 1985, pp. 88-89).

N. Glazkov declared uniqueness of his poetic view of the world: "I am taught by outworld experience» (Glazkov, 1989, p. 446); he insisted on connature of the invented form to complete freedom of the spirit: "I was against in my verses to / Any restrictions of theme / And my verse was anti-arsheen / That is my metric system" (1942) (Glazkov, 1989, p. 495). Moreover, "in a mad century of epochal war" (1944) (Glazkov, 1989, p. 506), the poet did not doubt the importance of his vocation: "For what Glazkov / Is no good for nothing, / Except the poetry, / He needs the Order" (1944) (Glazkov, 1989, p. 443). A. Tarkovsky admitted that aesthetic is alive in freedom from due and with trust in the elements of existence: "Why did I teach straightness to the staff? / Curvature to the bow, the grove to the bird? / Two palms, you're on a single string, / 
O reality and speech, widen my pupils, / Give me the communion of your kingly power". 3("Reality and Speech”, 1965) (Tarkovsky, 1993, p. 268). Minimalist V. Nekrasov perceived the originality of words, took ethical problems primarily as sound and visual images of concepts, rejoicing the most in rhyme, as a result of understanding the subtleties of semantics, "a shame and disgrace / we / compare» (Nekrasov, 2012, p. 293).

The third constitutive feature of intellectual consciousness is alienated lyricism, chilled sensitivity, claim to "objective subjectivity", in particular due to the rationality, analytic spiritual process, proposed and real internal discipline of mental work. The subjectivity itself is realized as detached and almost forked as a result of the desire for versatility of perception and self-awareness of even biographical "Self" as the dual form, loaded with diverse experience, which should be integrated. It is not a variety of feelings, but selfobservation, the attraction to generalization of details. So intellectual V. Bryusov remembered his peasant origins of worldview: "I am between the worlds. I am equal to the first / At a meeting of the nobility I am a peer, / And with every breath, every nerve / I echo the highest spirits of spheres. $<$...> But I was created from the dark clay / And bear its heavy burden. / I might have reached the top of the earth, - / My root is buried in the lowlands" (1911-1918) (Bryusov, 1972, p. 316). So Khlebnikov in the palindrome formula concluded about transitional continuity between the natural rebellion and revolution, made by an abstract mathematical genius: "I am Razin with the colours of Lobachevskian logs. // In the minds there is a candle, the pain; mene man, fall asleep, dawn" ("Razin", 1920) (Khlebnikov, 1986, p. 360).

N. Zabolotsky recorded the moment of transition from utopian, speculative natural philosophy ("The Triumph of Agriculture", 19291930, “Crazy Wolf”, 1931) to the natural line in the poem "The Onset of Winter" (1935), where he described the frozen river. The actual event, the shock of the discovery of the natural mind, is realized as a dialogue of the "Self", the carrier of human experience ("we") with the reader ("you"), to whom the poet is appealing, hoping to be convincing: "I watched as the river was dying, / Not a day or two, but just at that moment, / When it moaned in pain, / In its mind, it seems, I penetrated. / In a sad hour when the power was gone, / When around there was no anyone / Nature in the river showed us (emphasis added) / Trailing world of its consciousness. <...> And if you know (emphasis added) / How people see in the day of their death, / You will understand the river's glance" (Zabolotsky, 1985, p. 145). N. Glazkov ironically mocked at his own claim to exclusivity, and completed his self-portrait with an expressive formula of human self-consciousness in history: "I feel world in its greatness / generalizing even trifles. / As poets, I am full of indifference / To everything that is not poetry. $<\ldots>$ I gaze at the world from under the table, / The twentieth century is a century of extraordinary. / The more interesting is a century for the historian, / The sadder it is for a contemporary!" ("The Fantastic Years”, 1944) (Glazkov, 1989, p. 360).

A. Tarkovsky began his pathetic affirmation with significant slip of the tongue: "I am immortal until I die (emphasis added), / And for those who have not yet been born, / I tear space as the buzzer / Of phone of coming times" ("Buzzer", 1961) (Tarkovsky, 1993, p. 237). So the mission of a mediator maintained its organic nature, avoiding rhetorical beauty, alien to the intellectual reflection. Skeptical self-consciousness of V. Nekrasov, rebelling against the traditional lyric, excluded along a regular shape the need for the presence of the subject, therefore, it represented the self-reflection as the isolation in itself, while walking in a circle is absurd, which can only be broken by self-detachment: "I am I because I am 
I // but not I / and not I // and I did / without you / and I'll manage / without me" (Nekrasov, 2012, p. 49). However, "I" may be needed to assess the reality satirically, to playing objectivity: "Everything / everything is good / everything is good / everything // except me // except me / except me" (Nekrasov, 2012, p. 301).

The degree of theoretical setting of thinking is different for every author, this is due to the natural endowment, the inclination to abstract thinking, temper of a literary figure, and the degree of introverted isolation in their own discoveries. Cultural type of consciousness of V. Bryusov was not projective, but integrating and, in view of the vital determination to break "from the lowlands" to the summits, he was guided by intense communion with, development and broadcast of ready ideas, including decadent aesthetic escapism: "May be, in this life, all around / Is only the means for a verse. / And you from your childhood are bound / To seek combinations of words". ("To the Poet", December 18, 1907) (Bryusov, 1972, p. 316). Heuristic genius V. Khlebnikov developed a poetic version of the philosophy of unity; extreme, subjective sensitivity and belief in the universal kinship were organic for him; so he was looking for generalized, theoretical expression and considered the language to be alive intelligence of nature: “.... the simplest language saw the play of forces only. Maybe, these forces just rang in a language of consonants in the ancient mind. Only the growth of science will allow knowing all the wisdom of language, which is wise because it itself was a part of nature" ("The Teacher and a Student. On the Words, Cities, People", 1912) (Khlebnikov, 1986, p. 585).

N. Zabolotsky endured some evolution in the relentless quest for a holistic view of the world and the place of reason in the organic matter of being. His mind searched for an adequate language both in absurdic "Columns" and in the moral didacticism of late lyrics, where he declared panlogism: "And all existences, all the people / Stored imperishable being, / And I myself was not a child of nature, / But its thought! And its fragile mind it!" ("Yesterday, Thinking about Death", 1936) (Zabolotsky, 1985, p. 150). Also he experienced the despair of self-rejection: "And I am afraid to ponder, / That somewhere on nature's fringe / I'm that same blind man, / With face turned skyward in a cringe. / I watch the spring floods, / Only in my soul's depths dark, / Conversing with them / Only in my sorrowful heart". ("The Blind Man”, 1946) (Zabolotsky, 1985, p. 159). N. Glazkov, by contrast, was totally against both self-criticism and theoretical justification, though in the late $30 \mathrm{~s}$, during a celebration of the only possible method of socialist realism, he came up with an idea of a new direction. But the essence of "unprecedented forms" was not in formal discoveries, but in disobedience to the norm and actualization of modernism legacy: "As a worthy captain, the last / I leave the ship of futurism" ("I am not recognized by such untalented...") (Glazkov, 1989, p. 189). Art manifesto was boiled down to the declaration of the right to freedom of no regulated expression, namely the identity of the personal and creative will: "Poets know, for what they should fight, / Do not draw a dotted border to poets, / Do not break the spokes in a chariot / Flying along the creative ways" ("Nebyvalizm menia") (Glazkov, 1989, p. 186). The purpose of the flight was freedom itself: "I walk down the street, / The world before my eyes, / And the words being versed / Completely on their own" (Glazkov, 1989, p. 445).

A. Tarkovsky is the poet of meditative rather than conceptual thinking: he had a gift of a keen sense of life. In his poems ("Cactus" 1948, "Life, life...", 1965), he sought an adequate expression of the tragic force of vitality either in the biblical associations ("Star is dancing in front of the stars...”, 1968), or in the idea of hylozoism 
("Grygory Skovoroda", 1976). By actualizing the classics' experience the poet as if experienced, delved into deep and expressive, authoritative thinking, but did not line up his own philosophical system in search for ideas, probably because he shunned any schemes and lacked confidence in self-determination: "When nature and the dictionary enter into dispute, / The word tries to escape from the phenomena, / As a cast from the face, as the color from light and shade, - / Am I a beggar or o king? A scythe or a scytheman?" (1966) (Tarkovsky, 1993, p. 273). V. Nekrasov, in contrast, remained consistent theorist and practitioner of conceptualism as "avant-garde of avant-garde", because the method "goes further, in general, with the same objectives - to democratize art, to free it from the artificiality, requiring continuous checks on the widest, most lively reaction, to prevent authoritative "forms", styles, and preferred castes, to avoid cronyism, so that art will be our, common, living, constantly creative activity" (1982) (Nekrasov, 1996, pp. 284-285).

The principle of conceptualism is the birth of completeness of the statement from amorphous. The statement continuously enhances meanings in the process of reflection about "uncovered" words and the dynamics of their relationships in time and space: "Nothing nothing / nothing and nothing // nothing / nothing // everything" (Nekrasov, 2012, p. 301). Literary device is essentially reduced to the use of neutral material, free from discursive task and the emotional halo: "It is given // and to be proved / what / needs to be proved" (Nekrasov, 2012, p. 324). The lyrical story of the conceptual text is a heuristic process, which nothing predetermines, so the results are unpredictable, because there is no guarantee that the process will take place at all. So intellectual reaction of the reader is built into the form as a possible response to the provocation and complicity in the creation of meaning here and now. The alleged refusal of lyrical subjectivity elevates the status of the author to the detached demiurge, but sarcastically temperamental V. Nekrasov did not maintain that role in life and literary polemics, focusing his criticism on a heroic immorality of Yu. Kuznetsov and a cynical, intellectual speculation of D.A. Prigov.

Thus, the intellectual type of creative work along with the apparent chill of mental processes has a special passion to acquire the absolute truth. The truth can appear as a universal idea (for example, unity, panlogism, hylozoism), or as a way of thinking (in these cases - aestheticism, nebyvalizm (unprecedented things), conceptualism); the truth should be as close as possible to the non-dogmatic, heuristic understanding of the essential nature of things and relationships. Ideas can be refuted by experience but a way of thinking is not to be criticized, because it expresses the quality of lyricism - the very substance of the creative gift, a personal spiritual potential of the author. Poet as a discoverer or explorer of the truth does not inherit the romantic-mystical tradition of the chosen person, the suckling of the Muses and other higher powers; poets are an objective representation on the behalf of reason, so they reckon themselves to be the continuation of reason's expression.

The main myth of the intellectual type of creativity is creating an image of the objective reason (as an example, the consciousness of nature, the collective memory, language, speech, poetry itself), the representation of their relationship with the reason as equal, resonant, co-author in its nature. The interaction is revealed in the poetics of artistic thought, representing the mind in action. Obviously, this is a subjective logic of the author's thinking, which is more or less fanciful, but it is realized as a resonance model of objective human relations with the outside world. While for the feeling consciousness the main value is the unique 
depth, strength, expressiveness of emotions, the subjectivity of intelligence is dominant associative and imaginary characteristics and the plot of thought development.

Intelligent type of art can be seen as meta mode, the artistic realization of "directed thinking”. It combines both poets tending to appear witty, meditative lyricists, philosophers, and "poets for poets". The spiritual potential of the intellectual type of poetry, as well as the emotional and directed one, is determined by the personality of the creator, rather than the status of poet-"intellectual", no matter how well read and ironic the poet is, no matter what sophisticated game the poet plays with the intertext. The criterion of meaningfulness in analytics is synthesis: encompassing thought, breadth of vision, the creation of a holistic image of the world in conjunction of heterogeneous things, the discovery of formulae of unity.

\footnotetext{
Here and further verses are given in literal translation.

Alternative translation by Gleb Afinogenov:

I'm sick and tired of all the words and words,

And I can stand no longer to exalt

The right to reasoned speech, when on my roof

All night, like widows, ragged leaves demand

Their entry. (translator's note)

Translated from Russian by Philip Metres \& Dmitri Psurtsev

Translated by Yevgeny Bonver, September, 2000

Translated by Christopher Fortune.
}

\section{References}

1. Bryusov, V.Ya. Stikhi [Verses]. M., Sovremennik, 1972, 400 p.

2. Chernigovskaia, T.V. Cheshirskaia ulybka kota Sredingera: iazyk i soznanie [Schrödinger cat with a Cheshire Cat smile: language and consciousness]. M., Iazyki slavianskoi kul'tury (Languages of Slavic culture), 2013, $448 \mathrm{p}$.

3. Dubin, B. Klassika posle i riadom: Sotsiologicheskie ocherki o literature i kul'ture. Sbornik statei [Classics after and nearby: Sociological essays on literature and culture. Collecte]d works. M., Novoe literaturnoe obozrenie, 2010, 345 p.

4. Dubrovskii, D.I. (ed.) Problema soznaniia v filosofii i nauke [Problem of consciousness in philosophy and science]. M.: "Kanon+ Rehabilitation", 2009, 472 p.

5. Ershova, G.G. Asimmetriia zerkal'nogo mira [The asymmetry of the mirror world]. M., RSHU, 2003, 258 p.

6. Glazkov, N.I. Izbrannoe [Selected works]. M., Khudozhestvennaia literatura, 1989, 541 p.

7. Jung, C.G. Psikhologicheskie tipy [Psychological Types]. M., AST: AST MOSCOW: KHRANITEL', 2008, 761 p.

8. Khlebnikov, V. Tvoreniia [Creations]. M. "Sovetskii pisatel”, 1986, 736 p.

9. Khodasevitch, V. Koleblemyi trenozhnik: izbrannoe [Shaken tripod: selected works]. M., Sovetskii pisatel', 1991, 688 p.

10. Lirika: genesis evoliutsiia [Lyrics: the genesis of the evolution]. M., RSHU, 2007, $417 \mathrm{p}$.

11. Nekrasov, V. (1996). Kontsept kak avangard avangarda [Concept as avant-garde of the avantgarde]. Paket (Package) ed.by A. Zhuravleva, V. Nekrasov. M., Publishing House "Meridian”, 1996. Pp. 282-298.

12. Nekrasov, V. Stikhi [Verses] 1956-1983. Vologda: Polygraph-Kniga, 2012, 591 p. 
13. Ortega y Gasset, J. "Degumanizatsiia iskusstva" i drugie raboty. Esse o literature i iskusstve ["Dehumanization of Art" and other works. Essays on literature and art]. M., Raduga, 1991, 639 p.

14. Tamarchenko, N.D. Teoriia literatury: uchebnoe posobie [Theory of literature: textbook]. In 2 vols. Vol. I. M., Publishing Centre "Akademiia”, 2007, 512 p.

15. Tarkovsky, A. Blagoslovennyi svet: izbrannye stikhotvoreniia [Blessing light: selected poems]. Saint-Petersburg, Severo-Zapad, 1993, 368 p.

16. Veidle, V.V. Umiranie iskusstva. Razmyshleniia o sud'be literaturnogo i khudozhestvennogo tvorchestva [Dying art. Reflections on the fate of literary and artistic creativity]. Saint-Petersburg, Axioma, Mifril, 1996, $336 \mathrm{p}$.

17. Zabolotsky, N. Stikhotvoreniia i poemy [Verses and poems]. M.: Pravda, 1985, 512 p.

\title{
Интеллектуальный тип творчества (поэзия)
}

И.И. Плеханова

Иркутский государственный университет Россия, 664025, Иркутск, Чкалова, 2

\begin{abstract}
На примере поэзии рассматривается интеллектуальный модус творчества как выражение тенденции художественного мышления XX века. Интеллектуализм трактуется как «направленное мышление» (К.Г. Юнг), т.е. доминирующая в творчестве рачиональность. Выделены определяющие установки интеллектуального типа творчества: самосознание искусства, рефлексия гнозиса, приоритет эстетики над этикой, отчуждённый лиризм. Разнообразие форм иллюстрируют примеры поэзии старшего символиста B. Брюсова, будетлянина B. Хлебникова, обэриута H. Заболоикого, неофутуриста Н. Глазкова, натурфилософа А. Тарковского, минималиста-кониептуалиста Вс. Некрасова. Интеллектуальный тип творчества - при видимой охлаждённости духовных процессов являет особую страсть к обладанию абсолютной истиной. Истина может предстать как универсальная идея (например, всеединство, панлогизм, гилозоизм) или как образ мышления (в рассмотренных случаях - эстетизм, небывализм, концептуализм), максимально приближенный к недогматическому, эвристическому пониманию сущностной природы вещей и отношений.
\end{abstract}

Ключевые слова: интеллектуализм, «направленное мышление», лирика ХХ века, самосознание искусства, рефлексия гнозиса, приоритет эстетики, отчуждённый лиризм.

Научная специальность: 10.00.00 - филологические науки. 